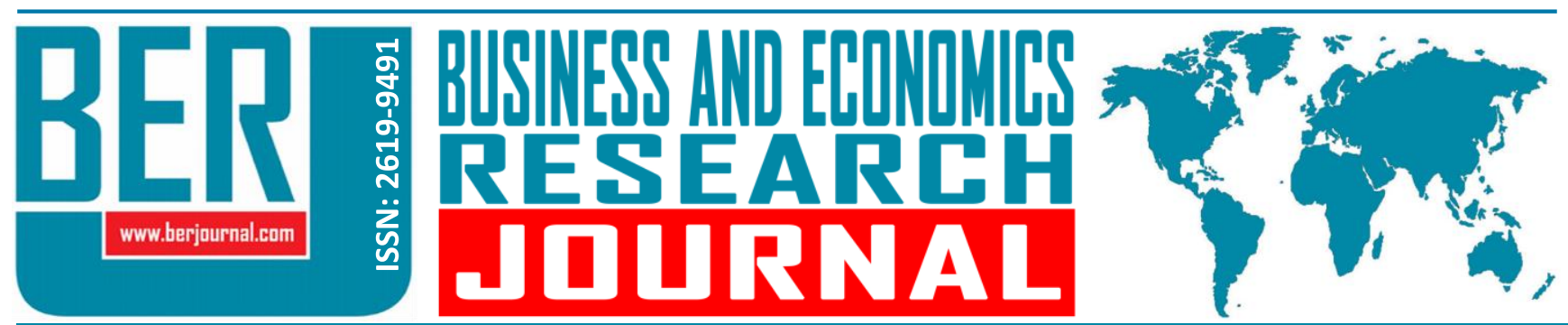

Business and Economics Research Journal Vol. 10, No. 4, 2019, pp. 959-972 doi: 10.20409/berj.2019.213

\title{
Exploring the Effects of Self-Image Congruity and Religiosity on Brand Equity of Grocery Stores
}

\author{
Yusuf Arslan ${ }^{\mathrm{a}}$, Nihal Sututemiz ${ }^{\mathrm{b}}$
}

Abstract: Although brand equity is a largely discussed concept in the marketing literature, the studies have mainly been subjected the marketing activities as the antecedents of brand equity. After a vast literature review, it is seen that, consumerbased antecedents of brand equity are neglected at a certain level. This study aims to fill that gap and explores the effects of consumers' religiosity and self-image congruity on the brand equity of grocery stores operating in an emerging economy. The universe of the study is determined as people above the age of 18 who do the most of their grocery shopping from one of the two retailers included in the scope of this study. The data were collected via a survey of 822 customers of two large grocery retailers in Turkey. The results show that both religiosity and self-image congruity have significant effects on the dimensions of retailers' brand equity except retailer awareness. This study contributes to the literature by enhancing the understanding regarding the effects of consumer-based antecedents on retailer brand equity in emerging markets.

Keywords: Retailer Brand Equity, Self-Image Congruity, Self-Concept, Religiosity, Retailing

JEL: M10, M31

Received : 14 March 2019

Revised : 26 April 2019

Accepted : 08 May 2019

Type : Research

\section{Introduction}

Retail brands increasingly aim to position their chains positively on the minds of consumers (Ailawadi \& Keller, 2004). One of the most important elements in positioning is creating strong brand equity (BE) for the retailer (Blackwell et al., 2006). For retailers, growing BE is a key objective achieved through gaining more favorable associations and feelings among consumers (Falkenberg, 1996). With high BE, it is easier for a retailer to preserve their customers (Christodoulides \& Chernatony, 2010). The importance of preserving existing customers can be better understood when the high costs of attracting new customers are taken into account (Blattberg \& Deighton, 1996).

In efforts to preserve customers through $\mathrm{BE}$, retailers must understand the drivers of $\mathrm{BE}^{1}$ in their effort to create and manage it. However, the literature does not provide clarity in this regard. To date, the studies in the related literature have focused heavily on marketing efforts as antecedents of BE (Yoo et al., 2000; Villarejo-Ramos \& Sanchez-Franco, 2005; Kim \& Hyun, 2010; Buil et al., 2013 etc.). Considering that BE largely resides on the mind of the customer (Keller, 1993), specific characteristics (e.g. lifestyle, beliefs) have the potential to affect how brands are perceived and thus BE is created. However, at present, the literature focusing on antecedents of retailer's BE, apart from marketing efforts, is limited. Few studies address the

a PhD., Sakarya University, Business Faculty, Department of Production Management and Marketing, Sakarya, Turkiye, yusufarslan@sakarya.edu.tr (ORCID ID: 0000-0002-1873-7567)

b Assoc. Prof., PhD., Sakarya University Business Faculty, Department of Management Information Systems, Sakarya, Turkiye, nihals@sakarya.edu.tr (ORCID ID: 0000-0002-8964-7198) 
effects of consumer based features of BE, especially for retailers BE (Swimberghe et al., 2009; Suki et al., 2014; Saeed \& Azmi, 2014-2015).

Through the purchase of specific products or visiting certain retailers, consumers define, maintain, and enhance their self-concept (Zinkhan \& Hong, 1991). This issue is encapsulated through self-image congruity theory (Sirgy, 1986). Accordingly, self-image congruity (SIC) has the potential to play a key role in retailer $\mathrm{BE}$. However, self-concept research addressing this issue has been limited. Even though there are studies addressing the relationship between SIC and dimensions of retailer' BE, (e.g., Ekinci \& Riley, 2003; Sirgy et al., 2000; O'Cass \& Grace, 2008) unpacking BE drivers in terms of self-image and religious characteristics has not been attempted. This is especially salient in the countries where religion plays a key role in daily lives of consumers.

According to shopping preferences theory, religiosity has a significant impact on consumers' shopping preferences and retailer choice (Sheth, 1981). While being highlighted as important (Bailey \& Sood, 1993), the research in this field remains scant (Swimberghe et al., 2009). There is limited research addressing the effects of religiosity on retailer' BE (see. Hirschman, 1981, 1982; Swimberghe et al., 2009; Yousaf \& Malik, 2012; Suki et al., 2014; Saeed \& Azmi, 2014) leading some to suggest that this topic needs more attention. Notably, the research addressing the role of the Islam has been neglected. Mostly other religious groups (e.g. Catholics and Jews) have been the primary focus of the previous studies (Ghorbani et al., 2002) and less attention has been paid to Muslim-dominated countries (O'Cass, et al., 2013). This study contributes to the literature by investigating the role of SIC and religiosity on creating BE for retailers operating in Turkey which is a Muslim-dominated country. Therefore, the effects of religiosity and self-image congruity on BE of grocery stores are examined in the current research. Correspondingly, the research question addressed in this study is: To what extent does the self-image congruity and consumer religiosity influence BE for retailers in emerging Islamic markets?

\section{Theoretical Background: Brand Equity, Self-Image Congruity and Religiosity}

There are two perspectives of BE which are financial and consumer based. In this research, the consumer based perspective of $\mathrm{BE}$, defined as the value that consumers associate with a brand, is adapted (Aaker, 1991). Accordingly, retailer BE can be defined as a set of brand assets and liabilities linked to a store brand (Arnett et al., 2003). Retailers' BE is a multidimensional concept that contains the dimensions loyalty to the retailer, retailer brand awareness, retailers' brand associations and retailers' perceived quality (Pappu \& Quester, 2006a; 2006b). Brand loyalty is a measure of the attachment that a customer has to a brand (Aaker, 1991). Brand awareness is the customers' ability to recall and recognize the brand as reflected by their ability to identify the brand under different conditions and to link the brand name, logo, symbol, and so forth to certain associations in memory (Keller, 2003). Brand associations consist of all brand-related thoughts, feelings, perceptions, images, experiences, and beliefs, attitudes (Kotler \& Keller 2016). Perceived quality is the customer's judgement about a product's overall excellence or superiority that is different from objective quality (Zeithaml, 1988). Further, retailer perceived quality proposed by Pappu \& Quester (2006a, b) comprises a broader concept and refers to the quality of goods and service together (Jinfeng \& Zhilong, 2009).

SIC and shopping preferences theories offer an important grounding to understand the effect of SIC and religiosity on retailers' $\mathrm{BE}$. SIC refers to a match/mismatch between the brand/brand user image and the consumer self-image (Johar \& Sirgy, 1991). The self-image and product image are described through shared constructs and, as such, there is a degree of congruence between self-concept and product concept (Ekinci \& Riley, 2003). In this regard, high self-congruity occurs when the identified brand-user image is perceived to match the consumer's self-image, while low self-congruity occurs when the consumer perceives a minimal match between the brand-user image and the consumer's self-image ( $O^{\prime}$ Cass \& Lim, 2002). Religiosity is the degree to which beliefs in specific religious values and ideals are held and practiced by an individual (Delener, 1990) which is not only a belief in the spiritual nature of man, but also a cultural element that determines the norms of society (Muhamad \& Mizerski, 2010). One of the most important aspects of religion is its effects on people's daily life (Glock \& Stark, 1965). This aspect of religion comprises the effects of religion on the 
individual's daily routines (Hökelekli, 1993). An individual may believe in god and pray, but may not reflect his / her beliefs in daily routines.

One of the most comprehensive frameworks of shopping preferences is shopping preferences theory, which is a part of Sheth's (1981) integrative theory of retail store patronage preference and behavior. Sheth (1981) identifies four determinants of shopping preferences which are; market determinants, company determinants, personal determinants and product determinants. One particular determinant of personal values identified by Sheth (1981) is religiosity which is especially focused in this study. According to the theory, shopping motives are determined by personal determinants. These personal determinants refer to customer-specific factors that influence and determine a customer's shopping motives. An individual's personal values and beliefs about what to look for while shopping for various products reflect that a shopper's personality maybe determined by such personal traits as religiosity.

\section{Hypothesis Development}

\subsection{The Effect of Self-Image Congruity on Retailers' Brand Equity}

According to self-image congruity theory, consumers have favorable perceptions of products and brands perceived to be congruent with their self-image because they seek self-consistency (Sirgy, 1982). Consumers' need for self-consistency in the case of retailing is the underlying source of motivation linking self-congruity with brand attitude and loyalty (e.g., Kressman et al., 2006; Sirgy \& Samli 1985; Sirgy et al., 1991). To reach self-consistency, people are motivated to hold a set of beliefs about themselves and act in ways (e.g., use goods and services) to reinforce their self-concepts (Sirgy et al., 2008). To satisfy the consumer's need for self-consistency, consumers tend to evaluate their own brand positively. Consumers' need for self-consistency also motivates brand loyalty (Kressman et al., 2006).

Thus, the greater the degree of self-congruity with a particular retailer is, the greater the possibility, which the customer creates positive associations and becomes loyal to that retailer to reach self-consistency, occurs. Also, the more similar a consumer's self-image is to the brand's image, the more favorable their evaluations of that brand should be (Graeff, 1996). Besides, the more closely consumers perceive themselves with the stereotypical image of a brand user, the more likely they will possess favorable evaluative judgments about the brand's quality (Das, 2015). Furthermore, in another study, Sotiropoulos (2003) concluded that liking the brand is expected to be higher in the case of high self-congruity situation. To this end, we can expect from a customer of a specific retailer to have high awareness, to be loyal, to have positive associations and to better evaluate its product quality. Therefore, it can be stated as follows:

H1a: Self-image congruity has a significant effect on brand loyalty towards the retailer.

H1b: Self-image congruity has a significant effect on brand associations towards the retailer.

H1c: Self-image congruity has a significant effect on retailer's perceived quality.

H1d: Self-image congruity has a significant effect on brand awareness of the retailer.

\subsection{The effect of Consumers' Religiosity on Retailers' Brand Equity}

From the consumer behavior perspective, religion, as a fundamental cultural value, greatly influences attitudes and other behavioral outcomes (Delener, 1994; Koc, 2012). According to the shopping preferences theory, a consumer's religion has the potential to shape his / her shopping motives (Sheth, 1981) and also brand choices (Khan, et al., 2013). Choosing specific brands or the products used by the members of the group is one of the basic characteristics of religious social groups (Odabasi \& Baris, 2007).

Religiosity is considered as an important store evaluation criterion and influences customers' decisions whether to be loyal or not towards the store. When marketing activities seem to contradict consumer's religious beliefs, this may lead to a biased interpretation of store evaluation criteria, ultimately resulting in a decrease in store loyalty (Swimberhe et al., 2009). When marketing and retailing activities contradict customers' religious values, there might be consequences for the retailer such as creating bad 
attitudes in consumers' mind or harming their BE. For instance, after Danish newspaper "Jyllends-Posten" published cartoons of Prophet Muhammad on September 2005, Muslims all over the world staged demonstrations and were urged to boycott Danish goods in protest (Browne, 2006). During the boycott, Europe's the second largest dairy company named "Arla Foods" (Danish retailer) claimed that the supermarkets in Muslim countries removed their products because the consumers did not want to buy those products. The boycott of Arla's products in the Middle East, cost them around 54 million Euros (Al-Hyari, et al., 2012). As it is seen, for Muslim consumers, Islam as being their religion has a great importance and also strongly influences their behaviors that can severely hurt the brand equity of business organizations in Muslim countries (Saeed \& Azmi, 2015). Further, religiosity serves as a lens through which individuals perceive themselves (Kadic-Maglajlic et al., 2014). Because consumer based brand equity is also a perception that a consumer holds for a particular brand, we believe that a consumer's religiosity and retailer' brand equity must be interrelated. Therefore religiosity is expected to have an impact on our focal dimensions of $B E$. For this reason, we propose,

H2a: Consumer religiosity has a significant effect on brand loyalty towards a retailer.

$\mathrm{H} 2 \mathrm{~b}$ : Consumer religiosity has a significant effect on brand associations towards a retailer.

$\mathrm{H} 2 \mathrm{c}$ : Consumer religiosity has a significant effect on a retailer's perceived quality.

$\mathrm{H} 2 \mathrm{~d}$ : Consumer religiosity has a significant effect on brand awareness of a retailer.

\section{Method}

\subsection{Research Design}

The research context of grocery retailing in Turkey was selected to test the research model as shown in Figure 1. The retailers BIM and Migros were selected as brand stimuli considering their relative importance in the market. BiM is the 24th and Migros is the 37th fastest growing retailer in the world between the periods 2011-2016. They are also the biggest retailers in Turkey in terms of annual income (Deloitte-Global Powers of Retailing, 2017). The research conducted empirically by analyzing the data obtained via structural equation modeling.

\subsection{Data Collection}

The population of this study determined as the Turkish citizens living in Turkey and purchasing most of their groceries form the retailers BiM and Migros. The respondents were chosen from the cities of Kocaeli and Sakarya which are the cities that quite rich in terms of the population of the focal retailers. A questionnaire was administrated to collect the data and a mall intercept was used in the data collection process. Within $95 \%$ confidence level, 384 observations are enough to represent a population one million and more. However, it is known from the literature that the bigger the sample size, the less the possibility of making mistakes regarding generalizations of the results to the whole population (Coşkun et al., 2017: 143). Additionally, considering the big size of the population of the study, which is 82 million Turkish citizens, 1000 questionnaires were distributed. Professional help was provided for the implementation of the questionnaires nearby of the focal retailers, between the periods of November-December 2016. Each respondent completed the survey only for one retailer if they were to agree that they were doing most of their shopping from the focal grocery stores. Totally, 822 properly answered questionnaires were obtained using convenience sampling method. As the survey instrument was originally designed in English, it was necessary to translate the items into Turkish before administration. The process involved two rounds of translation, first from English into Turkish and then back translation from Turkish into English, to ensure that the original meanings of the scale items were captured (O'Cass et al., 2013).

\subsection{Measures}

The method of Ericksen \& Sirgy (1992) was used in order to measure self-image congruity. The method is based on tapping the subject's perception of the product-user image, the subject's perception of 
his or her self-image in relation to the product-user image, mathematically computing a discrepancy or ratio score with each image dimension, and then summing the discrepancy scores across all dimensions (Claiborne \& Sirgy, 1990). Because of the recommendations in the literature (Osgood et al. 1975), a new scale suitable for the research purposes was created. Self-image congruity was measured with the help of the bipolar scale using the personality attributes obtained in the qualitative preliminary study. Both actual and ideal self-image congruity were measured using the same bipolar scale. Here, a similar method was used as in Zimmer \& Golden (1988) during scale development process. An 8-step process was carried out to develop a new scale to measure self-image congruity within the scope of the current study:

Stage1: By giving an open ended form to 40 customers, the respondents were questioned, which personality items they would use to describe the typical customer of retailers BiM and Migros. Totally, 207 adjectives were gathered.

Stage 2: All adjectives were subjected to a classification for both retailers by three coders who are two authors of the study and an academic who is an expert in qualitative studies. Themes were created separately for two retailers.

Stage 3: A focus group interview with nine experts was conducted. The experts included in the process were all academic in the relevant research area especially competent in qualitative studies. The participants were asked to group the expressions obtained for two retailers. Thus, a number of themes were created separately for two retailers.

Stage 4: The similarities and differences in the groups were determined by comparing the categories obtained from the previous grouping process. Then, three experts identified the adjectives in the categories obtained from the focus group interview as codes and rearranged them according to their frequency.

Stage 5: In this stage, a literature review was carried out to obtain the personality expressions used in similar studies (Aaker, 1997; Somer, 1998; Goldberg \& Somer, 2000; Aksoy \& Özsomer, 2007; Geuens et al., 2009; Bacanlı, 2009).

Stage 6: The reason for using this method is to be able to develop a common bipolar scale instead of developing a separate scale for both retailers. The items obtained from the literature were also included in the analysis and the codes and categories matching each other were mapped by three experts.

Stage 7: The item pool was reduced to 66 items by three experts considering the usage frequency in the literature, in which theme the statements take place and the frequency values obtained in the first study are performed by the researchers.

Stage 8: The items were converted into a bipolar form by the researchers with 20 bipolar, a total of 40 adjectives. Bipolar scale was re-evaluated by the researchers following the recommendations of Birdwell (1968) and the final scale was formed. The last form of the scale consists of 28 adjectives in a bi-polar form. ${ }^{2}$

Religiosity was measured using the 8 item measure of Yapıcı (2006) who adapted the scale from Glock \& Stark (1965) from the dimension of the effects/consequences. Also a control question was added to the scale to enhance the reliability. The items were rated on a five-point Likert-type in the scale. BE was measured following the approach of Pappu et al. (2005). Because measuring BE is context specific (Christodoulides \& Chernatony, 2010) to have a better measurement for the BE of the retailers in question, major studies on this subject have also been examined in detail and some additions have also been made to the scale so as to have a better measurement for the notion (Taylor et al., 2004; Pappu \& Quester, 2006-b; Jinfeng \& Zhilong, 2009, Gil-Saura et al., 2013 and Choi \& Huddleston, 2014). Finally, to measure the retailer's BE, 16 items were used, of which, four items each to measure brand loyalty \& brand associations and three items for each perceived quality \& brand awareness. Items were rated on a five-point Likert-type scale.

\subsection{Common Method Bias}

Several steps were taken in order to minimize the common method bias. First of all, the questionnaire design suggestions of MacKenzie \& Podsakoff (2012) were followed. In this regard, a pre-test was conducted 
on 30 university students to see if they would have problems understanding the items in the questionnaire. Minor changes were made according to the comments of the respondents. Different scale formats were also used in this study to avoid artifactual covariation produced by the use of the same scale format. Negative items corresponding to the positive ones were also added to the questionnaire to check consistency. To decrease the effect of social desirability, an introduction was added to the questionnaire to inform the respondents about the aim of the study. Secondly, a Harmon's single-factor test showing no single factor accounted for the majority of the variance (the first factor accounted for $23.28 \%$ of the $66.88 \%$ explained variance) was administrated.

\section{Analysis and Findings}

Structural equation modeling (SEM) was used in this study to test the proposed hypotheses illustrated in Fig. 1. Conforming to the accepted procedure (Bagozzi \& Yi, 2012), firstly an exploratory factor analysis was carried out by using SPSS 22 , then a confirmatory factor analysis and structural model analysis using AMOS 22 was done.

Figure 1. Research Model

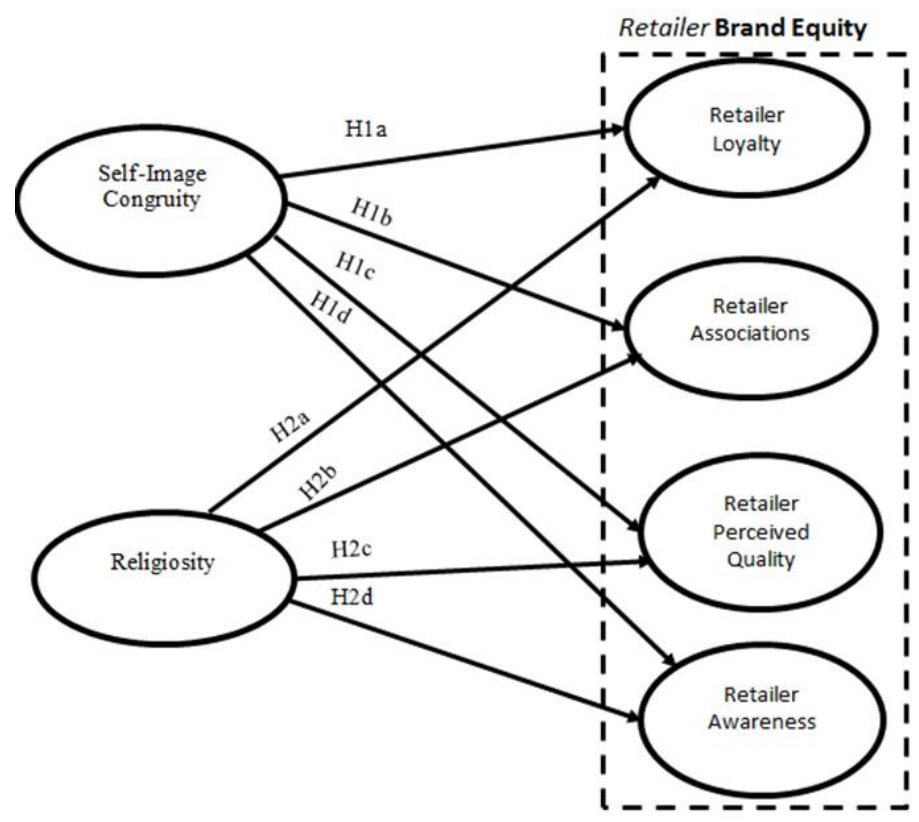

\subsection{Sample Characteristics}

The age range of the respondents was between 18 and 67 , that is to say, $40.8 \%$ of the respondents 25 years or under, $22.5 \%$ between $26-35$ years old, $19.1 \%$ aged $36-45$ years old, $13.3 \%$ aged between $46-55$ years old and $4.4 \%$ over 56 years of age; relatively evenly distributed across both education and income levels and the gender split (53.9\% female, $46.1 \%$ male).

\subsection{Measurement Estimation}

The results of preliminary analysis are shown in Table 1. Factor loadings for all constructs were higher than the critical point 0.50 (Hair et al., 2006). The Cronbach's alpha levels ranged from 0.76 to 0.94 , all exceeding the suggested critic level 0.70 (Bland \& Altman, 1997) ensuring the internal consistency and reliability for the factor structure.

Initially, the measurement model was estimated. The resulting measurement model displays acceptable ${ }^{3}$ goodness of fit statistics for the data, as indicated by $p<0.001 ; \chi 2 / d f=2.610 ; \mathrm{RMSEA}=0.044 ; \mathrm{GFI}=$ 0.941; AGFI=0.924; $\mathrm{CFI}=0.964 ; \mathrm{TLI}=0.957$. Table 1 summarizes the results of the measurement model including the values to assess reliability and validity. Discriminant validity was assessed following Fornell \& Larcker (1981). 
Table 1. Preliminary Results for the Measurement Model

\begin{tabular}{|c|c|c|c|c|c|c|c|}
\hline Items & $\stackrel{\omega}{>}$ & $\sum_{\underline{\Sigma}}^{O}$ & $\overrightarrow{4}$ & ૪ & $\stackrel{\Upsilon}{u}$ & $\stackrel{-}{\gtrless}$ & $<$ \\
\hline BRAND EQUITY of FOCAL RETAILER & 0.70 & 0.87 & & & & & \\
\hline Loyalty to the Retailer & 0.38 & & & & & & \\
\hline LOY2.A/B is my first choice for grocery shopping. & & & 0.84 & & & & 0.883 \\
\hline $\begin{array}{l}\text { LOY4. When I need to go grocery shopping, I will think of Retailer } \\
\text { A/B immediately }\end{array}$ & & & 0.81 & 0.87 & 0.875 & 0.638 & 0.776 \\
\hline LOY1.I consider myself to be loyal to A/B. & & & 0.81 & & & & 0.843 \\
\hline $\begin{array}{l}\text { LOY3. I will not buy products from other retailers, if I can buy the } \\
\text { same item at A/B stores. }\end{array}$ & & & 0.75 & & & & 0.679 \\
\hline Retailer Perceived Quality & 0.15 & & & & & & \\
\hline $\begin{array}{l}\text { PQ6. The quality of the products of Retailer } \mathrm{X} \text { is superior to other } \\
\text { retailers. }\end{array}$ & & & 0.89 & & & & 0.794 \\
\hline PQ7. A/B stores offer products of consistent quality. & & & 0.80 & 0.83 & 0.821 & 0.538 & 0.833 \\
\hline PQ1. A/B stores offer products of very good quality. & & & 0.74 & & & & 0.751 \\
\hline Retailer Associations & 0.10 & & & & & & \\
\hline AS5. A/B store merchandise offers value for money. & & & 0.75 & & & & 0.540 \\
\hline AS3.I trust A/B as a supplier of products. & & & 0.71 & 0.79 & 0.794 & 0.502 & 0.742 \\
\hline AS1.I like A/B stores. & & & 0.69 & & & & 0.703 \\
\hline AS2.I would feel proud to shop at A/B. & & & 0.62 & & & & 0.807 \\
\hline Retailer Awareness & 0.07 & & & & & & \\
\hline AW3.I can quickly recall the symbol or logo of A/B. stores. & & & 0.84 & & & & 0.751 \\
\hline AW2.I can recognize A/B among other stores. & & & 0.81 & 0.76 & 0.763 & 0.518 & 0.731 \\
\hline AW1.I am aware of A/B stores. & & & 0.81 & & & & 0.675 \\
\hline RELIGIOSITY & 0.65 & 0.93 & & & & & \\
\hline $\begin{array}{l}\text { RLG1. People should shape their daily lives in reference to their } \\
\text { religion. }\end{array}$ & & & 0.82 & & & & 0.775 \\
\hline RLG 2. It is necessary to generate religious generations. & & & 0.89 & & & & 0.881 \\
\hline $\begin{array}{l}\text { RLG } 3 . \text { I would prefer / preferred that the person I marry/would } \\
\text { marry is / be religious. }\end{array}$ & & & 0.87 & & & & 0.869 \\
\hline RLG 4. According to the Islam, women shouldn't shake hands with & & & 0.78 & & & & 0.741 \\
\hline $\begin{array}{l}\text { men. } \\
\text { RLG } 5 \text {. I do not drink because it is haram (because it is against } \\
\text { Islamic rules). }\end{array}$ & & & 0.85 & 0.941 & 0.920 & 0.596 & 0.804 \\
\hline RLG 6. I would prefer my friends to be religious. & & & 0.81 & & & & 0.773 \\
\hline $\begin{array}{l}\text { RLG 7. Because extramarital sexual experiences are forbidden in } \\
\text { Islam, I do not approach these kinds of acts. }\end{array}$ & & & 0.61 & & & & 0.513 \\
\hline $\begin{array}{l}\text { RLG } 8 \text {. It is appealing to me being seen as a good Muslim by my } \\
\text { social circle. }\end{array}$ & & & 0.80 & & & & 0.759 \\
\hline
\end{tabular}

As illustrated in Table 2, AVE values of each dimension are greater than the biggest values of latent variables squared correlations to each other, thus demonstrating satisfactory discriminant validity. All values met the criteria suggested by Schermelleh-Engel et al. (2003) also for convergent validity. All item loadings 
were higher than 0.50 , Composite Reliabilities were higher than 0.70 and all AVE values exceeded 0.50 as shown in Table 1.

Table 2. Discriminant Validity for the Latent Variables in the Research Model

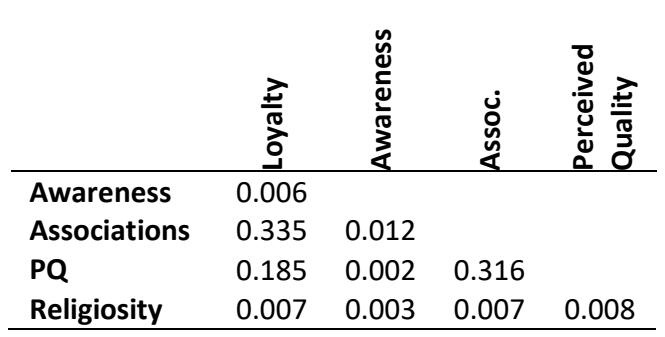

\subsection{Assessment of the Structural Model}

Structural equation modeling (SEM) was used in this study to test the relationships in the research model illustrated in Fig. 1. Regarding model fit indices, it is seen that the model satisfied the cut off points and fits well $(p<0.001 ; \chi 2 / d f=2.993 ; \mathrm{RMSEA}=0.049 ; \mathrm{GFI}=0.929 ; \mathrm{AGFI}=0.912 ; \mathrm{CFI}=0.953 ; \mathrm{TLI}=0.947)$.

\subsection{Results}

Presented in Table 3 is a summary of the results obtained by testing the hypotheses. According to the results it is seen that $\mathrm{SIC}$ has a significant effect on all dimensions of $\mathrm{BE}$, except for brand awareness. The effects on brand loyalty are $(\beta=0.700, p<0.001)$, perceived quality $(\beta=0.758, p<0.001)$, brand associations $(\beta=0.929, p p<0.001)$ and brand awareness $(\beta=.069, p=.123)$, respectively. Thus, while $H 1 a, H 1 b$, and $H 1 c$ were supported, $\mathrm{H} 1 \mathrm{~d}$ was rejected.

Table 3. Results of the Hypotheses

\begin{tabular}{llllll}
\hline & & $\begin{array}{c}\text { Std. } \\
\text { Reg. }\end{array}$ & C.R*. & $\mathbf{p}$ & Results \\
Weig. & & & \\
SIC $\longrightarrow$ Loyalty & 0.700 & 10.128 & $* * *$ & H1a Accepted \\
SIC & PQ & 0.758 & 10.159 & $* * *$ & H1b Accepted \\
SIC $\longrightarrow$ Associations & 0.929 & 10.062 & $* * *$ & H1c Accepted \\
SIC $\longrightarrow$ Awareness & 0.069 & 1.543 & 0.123 & H1d Rejected \\
RLG $\longrightarrow$ PQ & 0.082 & 2.222 & $\mathbf{0 . 0 2 6}$ & H2a Accepted \\
RLG $\longrightarrow$ Associations & -0.98 & -2.590 & $\mathbf{0 . 0 1 0}$ & H2b Accepted \\
RLG & 0.103 & 2.744 & $\mathbf{0 . 0 0 6}$ & H2c Accepted \\
RLG $\longrightarrow$ Awareness & 0.023 & 0.560 & 0.575 & H2d Rejected \\
\hline$* C . R .=$ Critic Ratio & & & & \\
\hline
\end{tabular}

The results also show that religiosity has an effect on all dimensions of $B E$ except for brand awareness. The effects, respectively, are as follows: on brand loyalty $(\beta=0.082, p=0.026)$, perceived quality $(\beta=-0.98, p=0.010)$, brand associations $(\beta=0.103, p=0.006)$ and on brand awareness $(\beta=0.023, p=0.575)$. Thus, while $\mathrm{H} 2 \mathrm{a}, \mathrm{H} 2 \mathrm{~b}, \mathrm{H} 2 \mathrm{c}$ were supported, $\mathrm{H} 2 \mathrm{~d}$ was rejected.

\section{Discussion and Implications}

The focus of this study was to contribute to the BE literature by examining the effects of religiosity and SIC on retailers' BE in an emerging market. Accordingly, it was concluded in the current study that 
consumer religiosity and self-image congruity are both valid antecedents of retailers' BE. As discussed earlier, a limited number of researches have been conducted assessing consumer based antecedents of $B E$ and most of the researches consider only the marketing efforts as antecedents of BE. By focusing on consumer based antecedents in this study, it was aimed to contribute to the literature regarding the role of consumer religiosity and self-image congruity in relation to BE creation in an emerging market.

With the current empirical study, it was revealed that SIC positively affects brand equity dimensions besides awareness. According to the findings of this research, SIC is an important factor predicting retailers' brand loyalty. Besides, the higher level of SIC is, the more favorable associations the consumers may develop. Thus, it can be put forward that consumers develop loyalty and positive associations to the retailers that they identify with their typical customers. Also, as SIC with the retailer increases, the tendency of the focal retailer to be perceived as quality will increase. Although prior research discussed this issue (e.g. Kressmann et al., 2006; Liu et al., 2012; Lu, 2014; Das, 2015), the number of the studies remains scant. Hence, the present study contributes to the literature by enhancing the understanding the effects of SIC on BE for the retailers operating in an emerging market.

In the second case, this study specifies the role of religiosity on BE dimensions. According to the results, religiosity significantly affects $B E$ dimensions besides awareness. First, it is seen that religiosity has a significant effect on loyalty to the retailer. However, prior research presents different findings about this issue. While some researchers concluded that religiosity has a negative effect on loyalty (Hirschman, 19811982; Swimberghe et al., 2009), Tiltay \& Torlak (2011) could not find any significant effects. By finding a significant positive effect of religiosity on brand loyalty, this study contributes to the literature by understanding the effects of religiosity on creating brand loyalty. Religiosity also has a positive effect on brand associations. For this reason, it can be concluded that as the level of religiosity increases, the consumer will have more positive associations for the focal retailers. With this finding, the present research contributes to the literature by enhancing the understanding of the effects of religiosity on brand associations. Religiosity also has a significant effect on the retailer's perceive quality. Although previous studies (e.g., Kadic-Maglajlic et al., 2014) revealed this relationship, there is a lack of understanding about this finding in the retail sector. With this finding, this research also contributes to the literature by enhancing the understanding of the effects of religiosity on perceived quality.

Although knowing that awareness is an important component of $\mathrm{BE}$, it was concluded in this study that both antecedents SIC and religiosity did not have any significant effects on it. Knowing that awareness levels were quite high for both retailers (BiM $=4.60$; Migros $=4.80$ out of 5 point Likert scale), it is considered that it does not come from the effects of antecedents in the current research model. Because both retailers are well known in Turkey, it can be asserted that their high awareness level comes from their intense marketing activities which are also other important antecedents of $\mathrm{BE}$.

The results indicate an insight for grocery retail brand managers operating in emerging economies. This study may also help practitioners to reposition themselves in the light of the findings by understanding these predictors of BE for a retailer. Considering the fact that people have higher BE levels towards the retailers that they identify with their typical customers, retailers should pay attention to the congruence between their target consumers' self-image and their brand image. By doing so, it becomes more likely that customers gain high levels of BE towards that retailer.

The Turkish FMCG sector as an emerging market has a highly competitive structure that also has the biggest growth potential in Europe. It is crucial for the retailers to have a high degree of BE so as to take the advantage of competing with other retailers. It is expected from the findings of this study to be a guiding light to the executives of Turkish FMCG sector with respect to the branding strategies they will develop. With this study, it is also aimed for the executives of Turkish FMCG sector to gain a consumer based perspective while designating their marketing strategies. Because it is clearly understood from the literature that the impact of religion on consumer behavior can differ from one country to another (Esso \& Dibb, 2004; Mokhlis \& Sparks, 2007), the current research also makes contribution to the literature by revealing the role of religion in $\mathrm{BE}$ creation in Turkish context. Considering religiosity is also a valid antecedent of $\mathrm{BE}$, the managers 
of Turkish grocery retailers should also pay attention to this phenomenon. Especially in the countries where Muslims are densely populated such as Turkey, ignoring religious beliefs of existing consumers may negatively affect the BE of the companies (Saeed \& Azmi, 2015). Thus, it is suggested to the managers that they should care about their potential customers' religious sensitivity in all their marketing activities. Otherwise, it is always possible for those customers to boycott the retailer or at least develop a bad image about the retailer that will definitely harm the BE.

\subsection{Limitations and Future Research}

This study has several limitations. First, this research was conducted among customers of retailers BiM and Migros in the cities of Kocaeli and Sakarya from Turkey. Secondly, due to the financial restrictions and the absence of a sampling frame that shows all the BiM and Migros clients as a list, convenience sampling method was used as the sampling method. For these reasons, it can be concluded that the sampling method and the used sample is too limited to generalize the whole population in Turkey. Furthermore, because BE and its antecedents were studied in relation to two specific retailers, it is possible for the outcomes to be different. Hence, future research may extend the findings of this research by comparing the relationships between different kinds of retailers. Future research can also be carried out to have a better understanding about the effect of consumer based antecedents (e.g. consumer values, peer influence) on the BE of retailers.

\section{End Notes}

1. In this study, brand equity is considered from the consumers' perspective.

2. See Appendix 1

3. See. Schermelleh-Engel et al. (2003).

\section{References}

Aaker, D. A. (1991). Managing brand equity. Simon and Schuster.

Aaker, J. L. (1997). Dimensions of brand personality. Journal of Marketing Research, 34(3), 347-356.

Ailawadi, K. L., \& Keller, K. L. (2004). Retail branding: conceptual insights and research priorities. Journal of Retailing, 80(4), 331-342.

Aksoy, L., \& Özsomer, A. (2007). Türkiye'de marka kişiliği oluşturan boyutlar. 12. Ulusal Pazarlama Kongresi Bildiriler Kitabı, 1-14.

Al-Hyari, K., Alnsour, M., Al-Weshah, G., \& Haffar, M. (2012). Religious beliefs and consumer behaviour: from loyalty to boycotts. Journal of Islamic Marketing, 3(2), 155-174.

Arnett, D. B., Laverie, D. A., \& Meiers, A. (2003). Developing parsimonious retailer equity indexes using partial least squares analysis: a method and applications. Journal of Retailing, 79(3), 161-170.

Bacanli, H., illhan, T., \& Aslan, S. (2009). Beş faktör kuramına dayalı bir kişilik ölçeğinin geliştirilmesi: Sıfatlara dayalı kişilik testi (SDKT). Journal of Turkish Educational Sciences, 7(2), 261-279.

Bailey, J. M., \& Sood, J. (1993). The effects of religious affiliation on consumer behavior: A preliminary investigation. Journal of Managerial Issues, 5(3), 328-352.

Bagozzi, R. P., \& Yi, Y. (2012). Specification, evaluation, and interpretation of structural equation models. Journal of the Academy of Marketing Science, 40(1), 8-34.

Birdwell, A. E. (1968). A study of the influence of image congruence on consumer choice. The Journal of Business, 41(1), 76-88.

Blackwell, R. D., Miniard, P. W., \& Engel, J. F. (2006). Consumer behavior (10th edition). Singapur: Thompson SouthWestern Corporation Inc.

Bland, J. M., \& Altman, D. G. (1997). Statistics notes: Cronbach's alpha. Bmj, 314(7080), 572.

Blattberg, R.C., \& Deighton J. (1996). Manage marketing by the customer equity test. Harvard Bus. Rev.,74(4), $136-44$. 
Brandfinance, (2015). Turkey $100 . \quad$ Retrieved June 06, 2016, from http://brandfinance.com/images/upload/brand_finance_turkey_100_2016_website_1.pdf

Browne, A. (2006). Denmark faces international boycott over Muslim cartoons. The Times.

Buil, I., De Chernatony, \& L., Martínez, E. (2013). Examining the role of advertising and sales promotions in brand equity creation. Journal of Business Research, 66(1), 115-122.

Chebat, J. C., Sirgy, M. J., \& St-James, V. (2006). Upscale image transfer from malls to stores: A self-image congruence explanation. Journal of Business Research, 59(12), 1288-1296.

Choi, L., \& Huddleston, P. (2014). The effect of retailer private brands on consumer-based retailer equity: Comparison of named private brands and generic private brands. The International Review of Retail, Distribution and Consumer Research, 24(1), 59-78.

Christodoulides, G., \& De Chernatony, L. (2010). Consumer-based brand equity conceptualisation and measurement: A literature review. International Journal of Market Research, 52(1), 43.

Claiborne, C. B., \& Sirgy, M. J. (1990). Self-image congruence as a model of consumer attitude formation and behavior: A conceptual review and guide for future research. Proceedings of the academy of marketing.

Coşkun, R., Altunışık, R. \& Yıldırım, E. (2017). Sosyal bilimlerde araştırma yöntemleri (9. Baskı). Adapazarı: Sakarya Kitabevi.

Das, G. (2015). Linkages between self-congruity, brand familiarity, perceived quality and purchase intention: a study of fashion retail brands. Journal of Global Fashion Marketing, 6(3), 180-193.

Delener, N. (1990). An examination of the religious influences as predictors of consumer innovativeness. Journal of Midwest Marketing, 5, 167-178

Delener, N. (1994). Religious contrasts in consumer decision behaviour patterns: Their dimensions and marketing implications. European Journal of Marketing, 28(5), 36-53.

Deloitte (2017). Global powers of retailing. Retrieved March 20, 2017, from https://www2. deloitte.com/content/dam/Deloitte/global/Documents/consumer-industrial-roducts/gx-cip-2017-globalpowers-of-retailing.pdf

Ekinci, Y., \& Riley, M. (2003). An investigation of self-concept: actual and ideal self-congruence compared in the context of service evaluation. Journal of Retailing and Consumer Services, 10(4), 201-214.

Ericksen, M. K., \& Sirgy, M. J. (1992). Employed females' clothing preference, self-image congruence, and career anchorage. Journal of Applied Social Psychology, 22(5), 408-422.

Esso, N., \& Dibb, S. (2004). Religious contrasts in consumer decision behavior. European Journal of Marketing, 28(5), 3653.

Falkenberg, A. W. (1996). Marketing and the wealth of firms. Journal of Macromarketing, 16(4), 4-24.

Fornell, C., \& Larcker, D. F. (1981). Evaluating structural equation models with unobservable variables and measurement error. Journal of Marketing Research, 18(1), 39-50.

Geuens, M., Weijters, B., \& De Wulf, K. (2009). A new measure of brand personality. International Journal of Research in Marketing, 26(2), 97-107.

Ghorbani, N., Watson, P. J., Ghramaleki, A. F., Morris, R. J., \& Hood Jr, R. W. (2002). Muslim-Christian religious orientation scales: Distinctions, correlations, and cross-cultural analysis in Iran and the United States. The International Journal for the Psychology of Religion, 12(2), 69-91.

Gil-Saura, I., Ruiz-Molina, M. E., Michel, G., \& Corraliza-Zapata, A. (2013). Retail brand equity: A model based on its dimensions and effects. The International Review of Retail, Distribution and Consumer Research, 23(2), 111-136.

Glock, C. Y., \& Stark, R. (1965). Religion and society in tension. Chicago: Rand McNally.

Goldberg, L. R., \& Somer, O. (2000). The hierarchical structure of common Turkish person-descriptive adjectives. European Journal of Personality, 14(6), 497-531.

Graeff, T. R. (1996). Using promotional messages to manage the effects of brand and self-image on brand evaluations. Journal of consumer marketing, 13(3), 4-18.

Hair, J. F., Black, W. C., Babin, B. J., Anderson, R. E., \& Ronald, L. T. (2006). Multivariate data analysis. Upper Saddle River, NJ: Pearson Prentice Hall.

Hirschman, E. C. (1981). American Jewish Ethnicity: Its relationship to some selected aspects of consumer behavior. The Journal of Marketing, 45(3), 102-110. 
Hirschman, E. C. (1982). Religious differences in cognitions regarding novelty seeking and information transfer. Advances in Consumer Research, 10, 228-33.

Hökelekli, H. (1993). Din psikolojisi. Ankara: Türkiye Diyanet Vakfı Yayınları.

Jinfeng, W., \& Zhilong, T. (2009). The impact of selected store image dimensions on retailer equity: Evidence from 10 Chinese hypermarkets. Journal of Retailing and Consumer Services, 16(6), 486-494.

Johar, J. S., \& Sirgy, M. J. (1991). Value-expressive versus utilitarian advertising appeals: When and why to use which appeal. Journal of Advertising, 20(3), 23-33.

Kadić-Maglajlić, S., Arslanagić, M., \& Čičič, M. (2014). Do national identity and religiosity antecede customer based brand equity in a developing multinational country? Journal of Euromarketing, 23, 111-123.

Kaya, (2015). Shirket analizleri. Retrieved August 17, 2017, from https://books.google.com.tr/books/about/Migros_Ticaret_A\%C5\%9E_Stratejik_Analiz.html?id=DhfSCQAAQBAJ \&redir_esc=y

Keller, K. L. (2003). Strategic brand management: Building, measuring, and managing brand equity. Aufl., Upper Saddle River.

Kim, J. H., \& Hyun, Y. J. (2010). A model to investigate the influence of marketing-mix efforts and corporate image on brand equity in the IT software sector. Industrial Marketing Management, 40(3), 424-438.

Koç, E. (2012). Tüketici davranışı ve pazarlama stratejileri: Global ve yerel yaklaşım. Seçkin Yayıncılık.

Kotler, P., \& Keller, K. L. (2016). Marketing management. Pearson.

Kressmann, F., Sirgy, M. J., Herrmann, A., Huber, F., Huber, S. \& Lee, D. J. (2006). Direct and indirect effects of self-image congruence on brand loyalty. Journal of Business Research, 59(9), 955-964.

Liu, F., Li, J., Mizerski, D. \& Soh, H. (2012). Self-congruity, brand attitude and brand loyalty: A study on luxury brands. European Journal of Marketing, 46(7/8), 922-937.

Lu, J. (2014). The role of self-congruity on Chinese young consumers' brand evaluation and brand loyalty toward sportswear brands. North Carolina State University, Unpublished Master Thesis.

Mackenzie, S. B., \& Podsakoff, P. M. (2012). Common method bias in marketing: Causes, mechanisms, and procedural remedies. Journal of Retailing, 88(4), 542-555.

Mokhlis, S., \& Sparks, L. (2007). Consumer religiosity and shopping behaviour in Malaysia. Malaysia Management Journal, 11, 87-101.

Muhamad, N., \& Mizerski, D. (2010). The constructs mediating religions' influence on buyers and consumers. Journal of Islamic Marketing, 1(2), 124-135.

O'Cass, A., \& Lim, K. (2002). The influence of brand associations on brand preference and purchase intention: An Asian perspective on brand associations. Journal of International Consumer Marketing, 14, 41-72.

O'Cass, A., Jin Lee, W., \& Siahtiri, V. (2013). Can Islam and status consumption live together in the house of fashion clothing? Journal of Fashion Marketing and Management: An International Journal, 17(4), 440-459.

O'Cass, A., \& Grace, D. (2008). Understanding the role of retail store service in light of self-image-store image congruence. Psychology and Marketing, 25(6), 521-537.

Odabaşı, Y., \& Barış, G. (2007). Tüketici davranışı. Mediacat.

Osgood, C. E., \& Suci, G. J., Tannenbaum, P. H. (1975). The measurement of meaning (9th ed.). Urbana: University of Illinois Press.

Pappu, R., Quester, P. G., \& Cooksey, R. W. (2005). Consumer-based brand equity: Improving the measurementempirical evidence. Journal of Product and Brand Management, 14(3), 143-154.

Pappu, R., \& Quester P. (2006-a). A consumer-based method for retailer equity measurement: Results of an empirical study. Journal of Retailing and Consumer Services, 13, 317-329.

Pappu, R., \& Quester, P. (2006-b). Does customer satisfaction lead to improved brand equity? An empirical examination of two categories of retail brands. Journal of Product \& Brand Management, 15(1), 4-14.

Saeed, M., \& Azmi, I. A. G. (2014). Religion and brand switching behaviour of Muslim consumers. Middle East J Sci Res, 21(9), 1611-1617.

Saeed, M., \& Azmi, I. A. G. (2015). Islam, brand image and intention: Influence of brand switching behaviour of Muslim consumers on brand equity. Proceedings of the 2 nd International Convention on Islamic Management 
Schermelleh-Engel, K., \& Moosbrugger H. (2003). Evaluating the fit of structural equation models: Tests of significance and descriptive goodness-of-fit measures. Methods of Psychological Research Online, 8(2), 23-74.

Sheth, J. N. (1981). An integrative theory of patronage preference and behavior. College of Commerce and Business Administration, Bureau of Economic and Business Research, 9-28

Sirgy, M. J. (1982-a). Self-concept in consumer behavior: A critical review. Journal of Consumer Research, 9(3), $287-300$.

Sirgy, M. J. (1986). Self-congruity: toward a theory of personality and cybernetics. Praeger Publishers/Greenwood Publishing Group.

Sirgy, M. J., \& Samli, A. C. (1985). A path analytic model of store loyalty involving self-concept, store image, geographic loyalty, and socioeconomic status. Journal of the Academy of Marketing Science, 13(3), 265-291.

Sirgy, M. J., Johar, J. S., Samli, A. C., \& Claiborne, C. B. (1991). Self-congruity versus functional congruity: Predictors of consumer behavior. Journal of the Academy of Marketing Science, 19(4), 363-375.

Sirgy, M. J., Grewal, D., \& Mangleburg, T. (2000). Retail environment, self-congruity, and retail patronage: An integrative model and a research agenda. Journal of Business Research, 49(2), 127-138.

Sirgy, M. J., Lee, D. J., Johar, J. S., \& Tidwell, J. (2008). Effect of self-congruity with sponsorship on brand loyalty. Journal of Business Research, 61(10), 1091-1097.

Somer, O. (1998). Türkçe'de kişilik özelliği tanımlayan sıfatların yapısı ve beş faktör modeli. Türk Psikoloji Dergisi, 13(42), 17-32.

Sotiropoulos, V. (2003). Luxury fashion brands: the impact of embodied imagery on brand responses. Unpublished Doctoral Dissertation, Concordia University.

Suki, N. (2014). Does celebrity credibility influence muslim and non-muslim consumers' attitudes toward brands and purchase intention? Journal of Islamic Marketing, 5(2), 227-240.

Swimberghe, K., Sharma, D., \& Flurry, L. (2009). An exploratory investigation of the consumer religious commitment and its influence on store loyalty and consumer complaint intentions. Journal of Consumer Marketing, 26(5), 340347.

Taylor, S., Celuch, K., \& Goodwind, S. (2004). The importance of brand equity to consumer loyalty. Journal of Product and Brand Management, 13(4), 217-227

Tiltay, M. A., \& Torlak, Ö. (2011). Materyalist eğilim, dini değerler, marka bağlılığı ve tüketici ahlakı arasındaki ilişkiler. Iş Ahlakı Dergisi, 4(7), 93-130.

Turkish Competition Authority (2012). Türkiye HTM perakendeciliği sektör incelemesi nihai raporu. Retrieved May 10, 2016, from http://www.rekabet.gov.tr/File/?path=ROOT \%2F1\%2FDocuments\%2FSekt\%25 c3\%25b6r \%2BRaporu\%2Fsektorrapor7.pdf

Villarejo-Ramos, A. F., \& Sánchez-Franco, M. J. (2005). The impact of marketing communication and price promotion on brand equity. Journal of Brand Management, 12(6), 431-444.

Yapıcı, A., \& Zengin, Z. S. (2003). Illâhiyat fakültesi öğrencilerinin değer tercih sıralamaları üzerine psikolojik bir araştırma: Çukurova Üniversitesi illâhiyat Fakültesi örneği. Değerler Eğitimi Dergisi, 1(4), 173-206.

Yapıcı, A. (2006). Yeni bir dindarlık ölçeği ve üniversiteli gençlerin dinin etkisini hissetme düzeyi: Çukurova Üniversitesi örneği. Çukurova Üniversitesi Ilahiyat Fakültesi Dergisi, 6(1).

Yoo, B., Donthu, N., \& Lee, S. (2000). An examination of selected marketing mix elements and brand equity. Journal of the Academy of Marketing Science, 28(2), 195-211.

Yousaf, S., \& Shaukat Malik, M. (2012). Evaluating the influences of religiosity and product involvement level on the consumers. Journal of Islamic Marketing, 4(2), 163-186.

Zeithaml, V. A. (1988). Consumer perceptions of price, quality, and value: A means-end model and synthesis of evidence. The Journal of marketing, 52(3), 2-22.

Zimmer, M. R., \& Golden, L. L. (1988). Impressions of retail stores: A content analysis of consumer images. Journal of Retailing, 64, 265-293.

Zinkhan, G. M., \& Hong, J. W. (1991). Self concept and advertising effectiveness: A conceptual model of congruency conspicuousness, and response mode. NA-Advances in Consumer Research, 18, 348-354. 


\section{Appendix}

Appendix 1. The Scale Used to Measure Self-Image Congruity

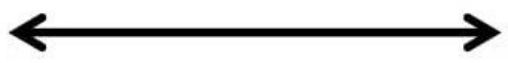

$$
\begin{array}{lllllll}
3 & 2 & 1 & 0 & 1 & 2 & 3
\end{array}
$$

Introvert

Strict

Tradational

Ordinary

Boring

Wasteful

Untidy

Modest

Religious

Unsatisfied

Extreme

Anxious

Energetic

Conservative

\begin{tabular}{|l|l|l|l|l|l|l|}
\hline & & & & & & \\
\hline & & & & & & \\
\hline & & & & & & \\
\hline & & & & & & \\
\hline & & & & & & \\
\hline & & & & & & \\
\hline & & & & & & \\
\hline & & & & & & \\
\hline & & & & & & \\
\hline & & & & & & \\
\hline & & & & & & \\
\hline & & & & & & \\
\hline & & & & & & \\
\hline & & & & & & \\
\hline
\end{tabular}

Extrovert

Flexible

Modern

Original

Fun

Economical

Tidy

Flashy

Secular

Satisfied

Restrained

Cool

Calm

Reformist 